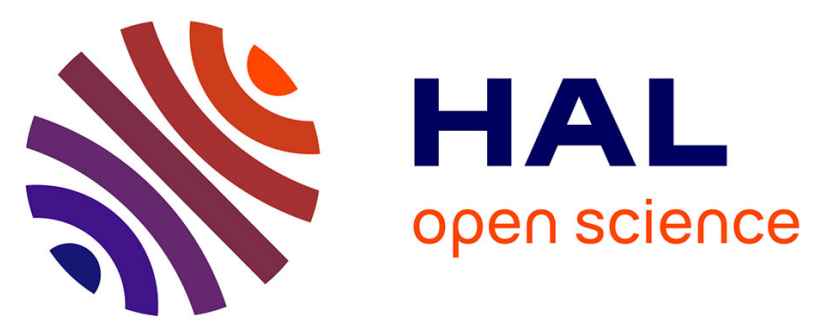

\title{
Forecasted consequences of simulated FAD moratoria in the Atlantic and Indian Oceans on catches and bycatches
}

\author{
Lauriane Escalle, Daniel Gaertner, Pierre Chavance, Alicia Delgado De
}

Molina, Javier Ariz, Bastien Mérigot

\section{- To cite this version:}

Lauriane Escalle, Daniel Gaertner, Pierre Chavance, Alicia Delgado De Molina, Javier Ariz, et al.. Forecasted consequences of simulated FAD moratoria in the Atlantic and Indian Oceans on catches and bycatches. ICES Journal of Marine Science, 2017, 74 (3), pp.780-792. 10.1093/icesjms/fsw187. hal-01928117

\section{HAL Id: hal-01928117 \\ https://hal.science/hal-01928117}

Submitted on 22 Nov 2018

HAL is a multi-disciplinary open access archive for the deposit and dissemination of scientific research documents, whether they are published or not. The documents may come from teaching and research institutions in France or abroad, or from public or private research centers.
L'archive ouverte pluridisciplinaire HAL, est destinée au dépôt et à la diffusion de documents scientifiques de niveau recherche, publiés ou non, émanant des établissements d'enseignement et de recherche français ou étrangers, des laboratoires publics ou privés. 


\title{
Original Article
}

\section{Forecasted consequences of simulated FAD moratoria in the Atlantic and Indian Oceans on catches and bycatches}

\author{
Lauriane Escalle, ${ }^{1,2, *}$ Daniel Gaertner, ${ }^{2}$ Pierre Chavance, ${ }^{2}$ Alicia Delgado de Molina, ${ }^{3}$ Javier Ariz, ${ }^{3}$ \\ and Bastien Mérigot ${ }^{1}$ \\ ${ }^{1}$ Université Montpellier, UMR MARBEC (IRD, Ifremer, Univ. Montpellier, CNRS), Av. Jean Monnet, CS 30171, 34203, Sète, France \\ ${ }^{2}$ Institut de Recherche pour le Développement, UMR MARBEC (IRD, Ifremer, Univ. Montpellier, CNRS), Av. Jean Monnet, CS 30171, 34203, \\ Sète, France \\ ${ }^{3}$ Instituto Español de Oceanografía, Apdo. Correos 1373, 38080 S/C Tenerife, Canary Island, Spain \\ *Corresponding author: tel: +33 (0)4 995732 14; fax: +33 4995732 95; e-mail: lauriane.escalle@yahoo.fr.
}

Escalle, L., Gaertner, D., Chavance, P., Delgado de Molina, A., Ariz, J., and Mérigot, B. Forecasted consequences of simulated FAD moratoria in the Atlantic and Indian Oceans on catches and bycatches. - ICES Journal of Marine Science, 74: 780-792.

Received 2 February 2016; revised 28 September 2016; accepted 3 October 2016; advance access publication 13 December 2016.

Given the increasingly extensive use of drifting fish aggregation devices (FADs) by the purse-seine fisheries targeting tropical tunas, fishing effort restrictions have been introduced to manage tropical tuna stocks. However, these measures are focused on the protection of juvenile tunas and do not take account of the potential impact on bycatch or associated megafauna (whales and whale sharks). An iterative "fishingday" Monte Carlo simulation model was developed to investigate the consequences on tropical tunas and bycatch of introducing extensive area 6-month moratoria on FAD activities. The model allowed for variability in a range of plausible values of the parameters characterizing the fishing operations conducted by European purse-seiners in the eastern tropical Atlantic and western Indian Oceans for the period 20052014. Monte Carlo simulations, using probabilities based on these fishery data, were carried out for the French and Spanish fishing fleets separately to account for differences in fishing strategies. The models predicted a decrease in FAD sets and an increase in free school sets. As a consequence, the catch of small tuna $(<10 \mathrm{~kg})$ decreased while the catch of large tuna $(\geq 10 \mathrm{~kg})$ increased, leading to an overall increase in tuna catch of 100-200 tons/year/vessel in the Atlantic Ocean, and a decrease of 400-1500 tons/year/vessel in the Indian Ocean. The bycatch decreased in the Indian Ocean, while in the Atlantic Ocean billfishes, turtles and chondrichthyans bycatch increased slightly and other bony fishes decreased. Because fishing practices were modified, whale and whale shark associated sets increased slightly in the Indian Ocean.

Keywords: bycatch, ecosystem approach to fisheries, fish aggregation device, megafauna, Monte Carlo simulations, time-area restriction, tropical tuna purse-seine fishery.

\section{Introduction}

Tropical tuna stocks are exploited by a wide range of industrial and small-scale fisheries. Worldwide, these tuna stocks are considered to be fully exploited or subject to overfishing (Juan-Jordá et al., 2011). This corresponds to the red quadrant of the Kobe plot commonly used by tuna Regional Fishery Management Organizations (tRFMOs) to summarize the results of stock assessment models (Kell, 2011). Concerns about the sustainability of tropical tuna stocks have led to the implementation of time-area restriction covering one or more fisheries and/or fishing modes (Torres-Irineo et al., 2011; Kaplan et al., 2014).

Historically, tropical purse-seiners detected tuna schools at the surface of the sea using visual cues, such as flocks of birds, disturbance on the surface of the water (e.g. breezers, foamers), natural floating objects (logs) or the presence of megafauna [whale sharks (Rhincodon typus), baleen whales, or pods of dolphins] (Ariz et al., 1999; Hallier and Parajua, 1999). These visual cues continue to be used, although, since the early 1990s, fisheries 
have been taking advantage of the aggregative behavior of tunas around floating objects to facilitate their catch. Thus, artificial floating objects (e.g. bamboo rafts) have increasingly being deployed since the early 1990s (Ariz et al., 1999; Hallier and Parajua, 1999). These, and other floating objects, may be equipped with satellite linked echo-sounder buoys providing fishers with accurate position and rough estimates of fish biomass (Lopez et al., 2014). These floating objects are classified as drifting fish aggregation devices (FADs) and the corresponding setting is designated as a "FAD set". FAD sets and sets on free-swimming tuna schools (termed hereafter "free school set") are the main purse-seine fishing modes in the eastern Atlantic and western Indian Oceans.

In these oceans, free school sets (and whale associated sets) mainly catch large yellowfin tunas (Thunnus albacares). FAD sets, on the other hand, catch mainly skipjack (Katsuwonus pelamis) as well as juvenile yellowfin and bigeye tunas (Thunnus obesus). FAD sets also have a much larger bycatch ratio than free school sets with a wider variety of species, including finfishes, billfishes, sharks (mainly silky sharks Carcharhinus falciformis), and turtles (Amandè et al., 2010, 2012; Bourjea et al., 2014). The increasing use of FADs has thus raised some concerns on (i) the recruitment of yellowfin and bigeye tunas, (ii) the potential modifications of original behavior of tuna and non-tuna species (i.e. "ecological trap", Marsac et al., 2000) and (iii) a negative alteration of the pelagic ecosystem due to high bycatch rates (Bromhead et al., 2003). Various measures to regulate fishing effort, such as moratoria on FAD activities (i.e. ban of all FAD activities) or no-take zones (i.e. ban of all purse-seine fishing activities), have therefore been implemented by tRFMOs in both the Atlantic and Indian Oceans to protect juvenile yellowfin and bigeye tunas. In the Atlantic Ocean, the first moratorium on FAD activities, initiated on a voluntary basis by European vessel owner companies, was in force from 1997 to 2004 for 3 months (November-January) over a large area of the Gulf of Guinea (Figure 1, Table A1; ICCAT, 1998). As the moratorium was progressively not respected by some purse-seine fleets, a one month no-take zone was then introduced in 2004 over a more limited area (ICCAT, 2004). A second moratorium on FADs in a different area of the eastern Atlantic Ocean was introduced in 2012 and is still currently in place for two months (January and February; ICCAT, 2011). In the Indian Ocean, a no-take zone was also introduced in 2010 over a large area east of Somalia but only for November (Figure 1, Table A1; IOTC, 2012).

In the light of the restrictions that have already been introduced in both oceans and their limited effects (i.e. not fully respected or considered too small to be effective, Torres-Irineo et al., 2011; Kaplan et al., 2014), the possibility of introducing more extensive moratoria has been suggested. This study set out to determine whether it is possible to use time-area moratoria over wider areas and for longer periods in order to (i) meet the tRFMOs target of reducing the mortality of juvenile tunas while (ii) meeting the Ecosystem Approach to Fisheries (EAF) aims of reducing the bycatch, and (iii) without increasing the impact on megafauna caused by the reallocation of effort from FAD sets to other fishing modes. Effects of extensive moratoria on tuna catch and bycatch were explored using Monte Carlo simulations of fishing effort reallocation. This was determined by selecting a path through the process potentially leading to a successful fishing set for each day of one fishing year based on the probabilities of decisions made by fishers, tunas encounter rates and fishing success.

\section{Material and methods Data}

Data were obtained from logbooks of the European tropical tuna purse-seiners (France and Spain) and associated flagged vessels. This is the main surface fishing fleet ( $\sim 70 \%$ of the purse-seine tuna captured) operating in the eastern Atlantic (since 1960s) and western Indian Oceans (since 1980s), although Ghanaian and Seychelles purse-seiners, among others, also operate respectively in these oceans (Fonteneau, 2009, 2010). Fishing activities (e.g. setting, moving between fishing areas) have been systematically recorded by skippers since 1990 (90\% coverage before this date). These are reported to the Institut de Recherche pour le Développement (IRD) for French vessels and the Instituto Español de Oceanografía (IEO) for Spanish vessels. To give an up-to-date picture of the situation and strategies of European purse-seiners, including the last technological changes, we selected logbook data for the last ten years (2005-2014). Each fishing set record includes (i) the date and geographical location, (ii) the cue, i.e. the association between the tuna school and floating objects [natural logs or FADs (in this study, when mentioning $\mathrm{FAD}$, it includes both natural log and FAD)], cetaceans, whale sharks, flocks of birds or free swimming tuna school and iii) the estimated catch of the set and the tuna species composition by commercial size category $(<10 \mathrm{~kg}, \geq 10 \mathrm{~kg})$. For data management purposes, the various fishing modes are then classified according to the cues for sighting the tuna school (FAD, free school, "whale associated set" or "whale shark associated set"). It should be noted that whale and whale shark associated sets are relatively rare events in both Atlantic and Indian Oceans $(\sim 1.5 \%$ and $\sim 3.0 \%$ of all fishing sets, respectively; Capietto et al., 2014; Escalle et al., 2015). In addition, their intentional setting has been banned in the Indian Ocean since 2013 (IOTC, 2013). On the basis of tuna species and size samples taken at landing sites, logbook data are corrected in order to reflect the tuna species composition per size category over large time-area strata (Pallarés and Petit, 1998). During this correction procedure, whale associated sets are combined with free school sets and whale shark associated sets with FAD sets. This corrected logbook dataset, useful for stock assessment purposes, was not used here because (i) data reported in logbooks are more representative in terms of commercial size category of the catch for each fishing set and (ii) in the corrected dataset the four initial fishing modes are simplified to free school and FAD sets only. However as the tuna species may not be correctly identified in the logbooks, the tuna catch per size category was used without detailed consideration of species: tuna $<10 \mathrm{~kg}$ (a mix of mostly skipjack tunas, juvenile yellowfin and bigeye tunas) and tuna $\geq 10 \mathrm{~kg}$ (a mix of mostly yellowfin and bigeye tunas) [many commercial size categories are reported in logbooks: skipjack tunas were entirely included in tuna $<10 \mathrm{~kg}$; most yellowfin and bigeye tunas categories were already corresponding to either $<10 \mathrm{~kg}$ or $\geq 10 \mathrm{~kg}$; one category (yellowfin and bigeye tunas between 6 and $20 \mathrm{~kg}$ ) was however redistributed as follow: $20 \%$ in tuna $<10 \mathrm{~kg}$ and $80 \%$ in tuna $\geq 10 \mathrm{~kg}$; yellowfin and bigeye catch with size unknown category were removed].

Data from scientific observers onboard French purse-seiners were also used to assess bycatch composition by large taxonomic groups. These data were collected by IRD from 2005 to 2014 as part of continuous data collection programs (i.e. European Union Data Collection Framework; Regulation (EC) No 199/ 2008). The coverage rate over the period considered was about 


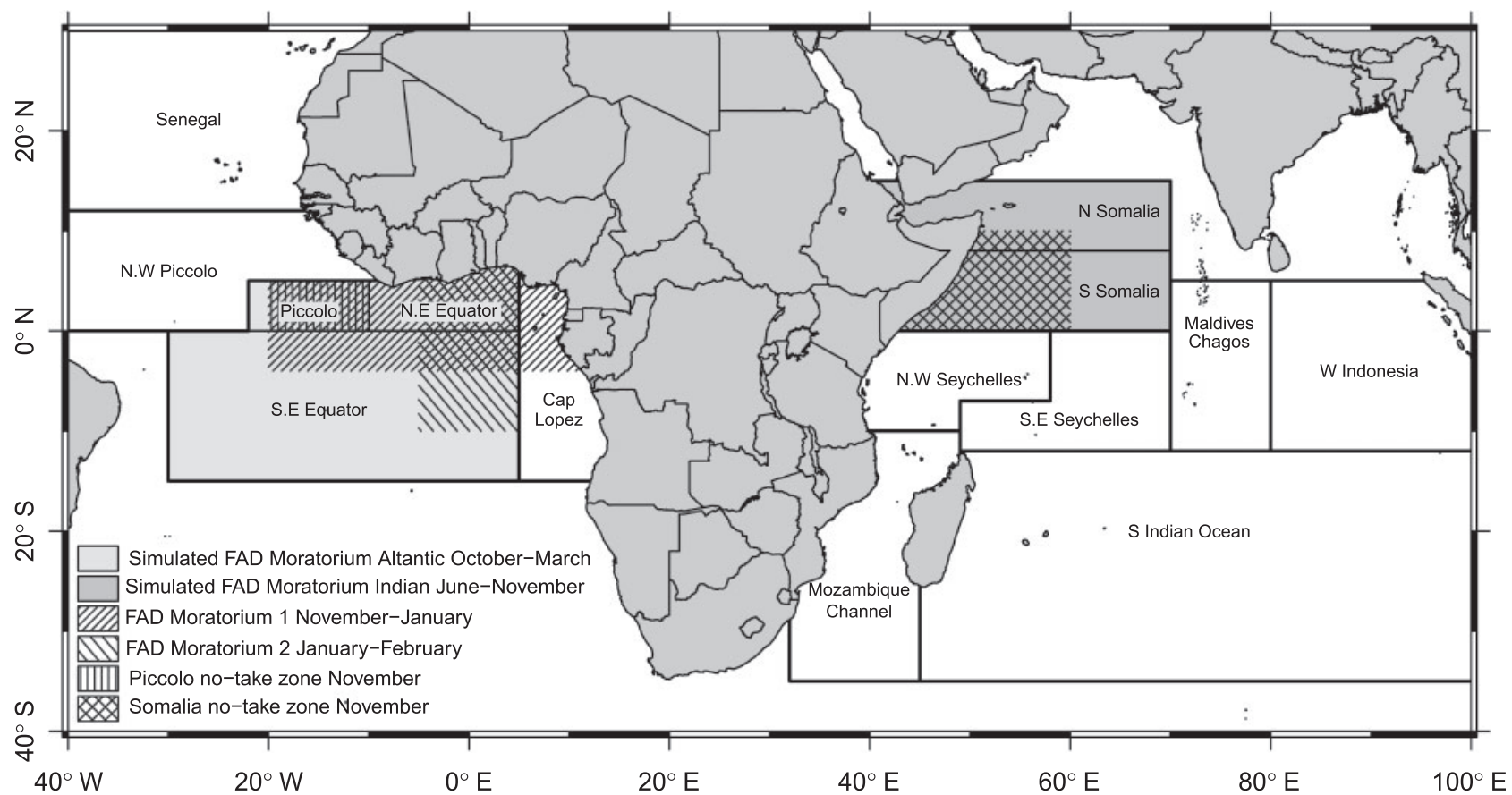

Figure 1. Subregions used by the European Union research institutes (IRD and IEO) for spatial sampling.

$23 \%$ of all fishing sets in the Atlantic Ocean (100\% since 2014) and $12 \%$ in the Indian Ocean (50\% since 2014). For each fishing set, the bycatch was identified by species, when possible, or else by taxonomic group (including discards of the target species). In this study, the bycatch was then assessed for each fishing set per taxonomic species group as follows: (i) other bony fishes (all bony fishes except the targeted tuna species and billfishes), (ii) billfishes, (iii) chondrichthyans (sharks and rays), and (iv) marine turtles.

\section{Subregions and periods}

The main fishing grounds of the European purse-seiners were divided into 6 sub-regions in the eastern Atlantic Ocean and 8 in the western Indian Ocean (Figure 1), following the stratification used by Pallarés and Petit (1998) for spatial sampling.

Given the difference in the oceanography of the two oceans, the Atlantic Ocean was stratified into four quarters, starting from January and labeled 1-4, while the Indian Ocean being strongly affected by seasonal monsoons, was stratified into two main monsoon periods [North-East (NE) from December to March (1) and South-West (SW) from June to September (3)] and two intermonsoon periods [South-West (ISW) in April-May (2) and North-East (INE) in October-November (4)] (Capietto et al., 2014; Escalle et al., 2015).

\section{Monte Carlo simulation General principle}

The strengths and weaknesses of a management regulation (i.e. time-area closure, moratorium) on a specific fishing practice can be evaluated by simulating the behavior-at-sea of the tuna purseseiners. The model must include all the steps from selecting a fishing ground to the realization of the set in a decision process. However, the various fishing choices or risks (e.g. setting on a specific fishing mode, the success of the set) describing purseseiner fishing operations are variable and difficult to quantify exactly, making it also difficult to predict the effect of a given regulation. In such context, Monte Carlo simulation can be used to propagate uncertainties in model inputs into uncertainties in model outputs. The uncertainties used as inputs are described using probability distributions, which define the range of values a variable may take (i.e. on the basis of historic data), and the probability of these values occurring.

In Monte Carlo simulation a large number of pseudo-random draws are taken from a uniform distribution with interval $[0,1]$. Then it assigns values less than or equal to the observed probability of an event (e.g. setting on a specific fishing mode, having a successful set (i.e. tuna caught)). The parameters for which random draws are taken are listed in Table 1. The process is then repeated over time to calculate the outputs of the process after changing certain probabilities as a result of a restriction. This gives a large number of separate, independent outputs. Each represents one possible path that the process might follow over time. The outputs (e.g. total tuna catch per size category, total bycatch per taxonomic group) are assembled into probability distributions of possible outcomes. As a result, the outputs of the model are not single values but probability distributions which can be used to calculate average values and corresponding confidence intervals. Monte Carlo methods have been used already to simulate the fishing strategies adopted by tuna fishermen (VacaRodríguez and Dreyfus-León, 2000) and to estimate the amount of billfishes bycatch in the European tuna purse-seine fishery in the eastern Atlantic Ocean (Gaertner et al., 2002).

\section{The iterative "fishing-day" model}

Monte Carlo simulations were used to incorporate all known sources of uncertainty in the analysis of the potential effect of sixmonth FAD moratoria on tuna catch, bycatch and megafauna 
Table 1. Parameters and conditional probabilities (italics) used in the Monte Carlo simulations of six-month moratoria on FAD activities, derived from European purse-seine fishery data.

\begin{tabular}{|c|c|}
\hline Symbol & Description \\
\hline i & Index of day in a restricted fishing season \\
\hline I & Total number of days in a restricted fishing season: 90 days in the Atlantic Ocean, 60 or 120 in the Indian Ocean \\
\hline $\mathrm{n} 1-\mathrm{n} 6$ & Random numbers drawn and compared to the probabilities $P a, P b, P c, P d, P f$ and $P e$ \\
\hline q & $\begin{array}{l}\text { Random number drawn and compared to the probability } P_{\text {stay }} \text { of staying in one of the subregion of the moratorium during day } i \\
\text { given the restriction }\end{array}$ \\
\hline j & Index of fishing set completed in day $i$ \\
\hline j & Total number of sets $\mathrm{j}$ during day $\mathrm{i}$ (depends on $\mathrm{Pb}$ ) \\
\hline $\mathrm{L}$ & Any of the free access subregion \\
\hline FM & Fishing mode: FAD, free school, whale associated, or whale shark \\
\hline $\mathrm{C}$ & Tuna catch $(t)$ in size category $\mathrm{c}(<10 \mathrm{~kg} ; \geq 10 \mathrm{~kg})$ \\
\hline B & Bycatch $(t)$ per taxonomic group. Note that an unsuccessful set (less than $1 \mathrm{t}$ of tuna catch) may have a bycatch \\
\hline $\mathrm{Pa}$ & $\begin{array}{l}\text { Probability of fishing activity on day i per sub-region: } P a_{\text {reg }} \text { in one of the sub-regions included in the moratorium on FAD activities } \\
\text { and } P a_{L} \text { in one of the unrestricted sub-regions } \mathrm{L}^{1}\left(\mathrm{~Pa}_{\text {reg }}<P a_{L}\right)\end{array}$ \\
\hline$P_{\text {stay }}$ & $\begin{array}{l}\text { Probability of staying in one of the sub-regions of the moratorium during day i given the restriction. } P_{\text {stay }}=0.21-0.82 \text { in the } \\
\text { Atlantic Ocean and } 0.03-0.19 \text { in the Indian Ocean, depending on the fleet, as well as each of the sub-region and period of the } \\
\text { moratoria }\end{array}$ \\
\hline $\mathrm{Pb}$ & $\begin{array}{l}\text { Probability of completing a given number of fishing sets }(J) \text { during day } i \text {, per sub-region }{ }^{1} . P b_{0} \text { represents the probability of } 0 \text { fishing } \\
\text { sets. } P b_{\text {J }} \text { represents the probability of J fishing sets }\end{array}$ \\
\hline Pc & Probability of each fishing mode FM: FAD, free school, whale associated, or whale shark associated set, per sub-region ${ }^{\mathrm{a}}$ \\
\hline$P c^{\prime}$ & $\begin{array}{l}\text { Adjusted probability of each fishing mode FM. When FAD sets are banned, its probability of the occurrence is redistributed among } \\
\text { the remaining fishing modes according to their probabilities }\end{array}$ \\
\hline$P d$ & $\begin{array}{l}\text { Probability of successful fishing set, for each fishing mode and sub-region. }{ }^{\text {a }} \text { The set is either successful (tuna catch) or unsuccessful } \\
\text { (less than } 1 \mathrm{t} \text { of tuna catch) }\end{array}$ \\
\hline $\mathrm{Pe}$ & $\begin{array}{l}\text { Probability of catching } C \text { tons of tuna in the set for each fishing mode and sub-region. Two probabilities } P e_{C 1} \text { and } P e_{C 2} \text { are used for } \\
\text { the two size categories: } C_{1} \text { tuna }<10 \mathrm{~kg} \text { and } C_{2} \text { tuna } \geq 10 \mathrm{~kg}^{\mathrm{a}}\end{array}$ \\
\hline Pf & 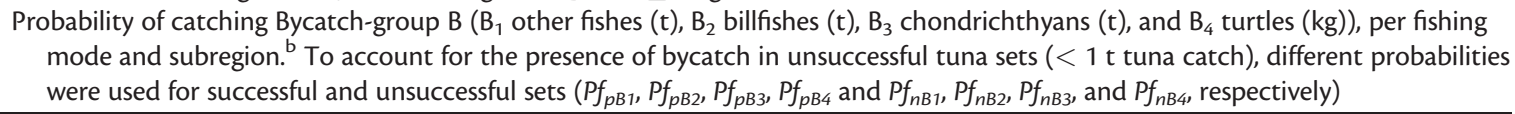 \\
\hline
\end{tabular}

${ }^{a}$ Because fishing effort by regions and choices in fishing modes may differ in terms of proportion between both fleets, these probabilities were calculated from French and Spanish logbooks separately.

${ }^{\mathrm{b}}$ The catch of bycatch by group, fishing modes and regions was assumed to be independent of the fishing fleet. Probabilities calculated using the French observers data.

associated sets. This was done for one vessel during one year from a designated fleet (French or Spanish) in the Atlantic Ocean or the Indian Ocean. French and Spanish purse-seiners behave differently in terms of fishing modes and spatio-temporal effort distribution with high seasonal, annual and spatial variability in the fishing strategy. French purse-seiners mainly target free swimming schools (average of 69 and $45 \%$ in the Atlantic and Indian Oceans, against 28 and $52 \%$ for FAD sets). In contrast Spanish purse-seiners mainly set on FADs (47 and 67\% in the Atlantic and Indian Oceans, against 52 and $34 \%$ for free schools). This difference may be explained by the fact that French crews are paid based on the value of the tuna catch (i.e. mostly targeting large tunas), while Spanish crews are mainly paid according to the tonnage captured (i.e. high number of small tunas under FADs). The simple iterative "fishing-day" model (Figure 2) allowed for random variation in 7 different conditional probabilities of the successive decisions or events (Table 1) that occurred for the vessel during each day: (i) presence in the restricted area (1 in Figure 2), (ii) change (or not) of sub-region given the moratorium (only if the vessel is present in the restricted area; 2 in Figure 2), (iii) the number of fishing sets completed during the related day ( 3 and 3 ' in Figure 2), (iv) the fishing mode for each fishing set (4 and 4' in Figure 2), (v) the success of the set (5 and 5' in Figure 2), (vi) the bycatch ( 6 and 6 ' in Figure 2 ) and (vii) the catch for each fishing set ( 7 and 7 ' in Figure 2 ). These were based on probabilities that were calculated using commercial fishery data from European tuna purse-seiners (logbook or scientific observer data depending on the probability) over the 2005-2014 period. Probabilities used in the simulation are thus reflecting the current fishing strategies, effort distribution, tuna catch and bycatch of the French and Spanish fleets. Conditional probabilities were calculated for each sub-region (see Section 2 for details; Figure 1), season (quarters in the Atlantic Ocean and monsoon or inter-monsoon periods in the Indian Ocean) and fleet (French or Spanish) and derived from cumulative probability histograms (see Figure 2 for histogram examples).

\section{Areas and period considered}

In order to simulate the potential impact of six-month large FAD moratoria, various scenarios, based on historical data from the European tuna purse-seine fishery were used as the basis for the simulation. The areas (Figure 1) and periods considered for the simulated moratoria were those with the highest number of FAD sets (see Figures 3 and 4). This was chosen in order to be able to compare the consequences between the existing time-area FAD moratoria and the larger and longer ones simulated. In the Atlantic Ocean, the simulated FAD moratorium covered the Piccolo, NE Equator and SE equator sub-regions during seasons 1 and 4 (i.e. October-March; Figures 1, 3 and 4), where FAD sets accounted for $37.3 \pm 14.0 \%$ of the sets for the French fleet and 


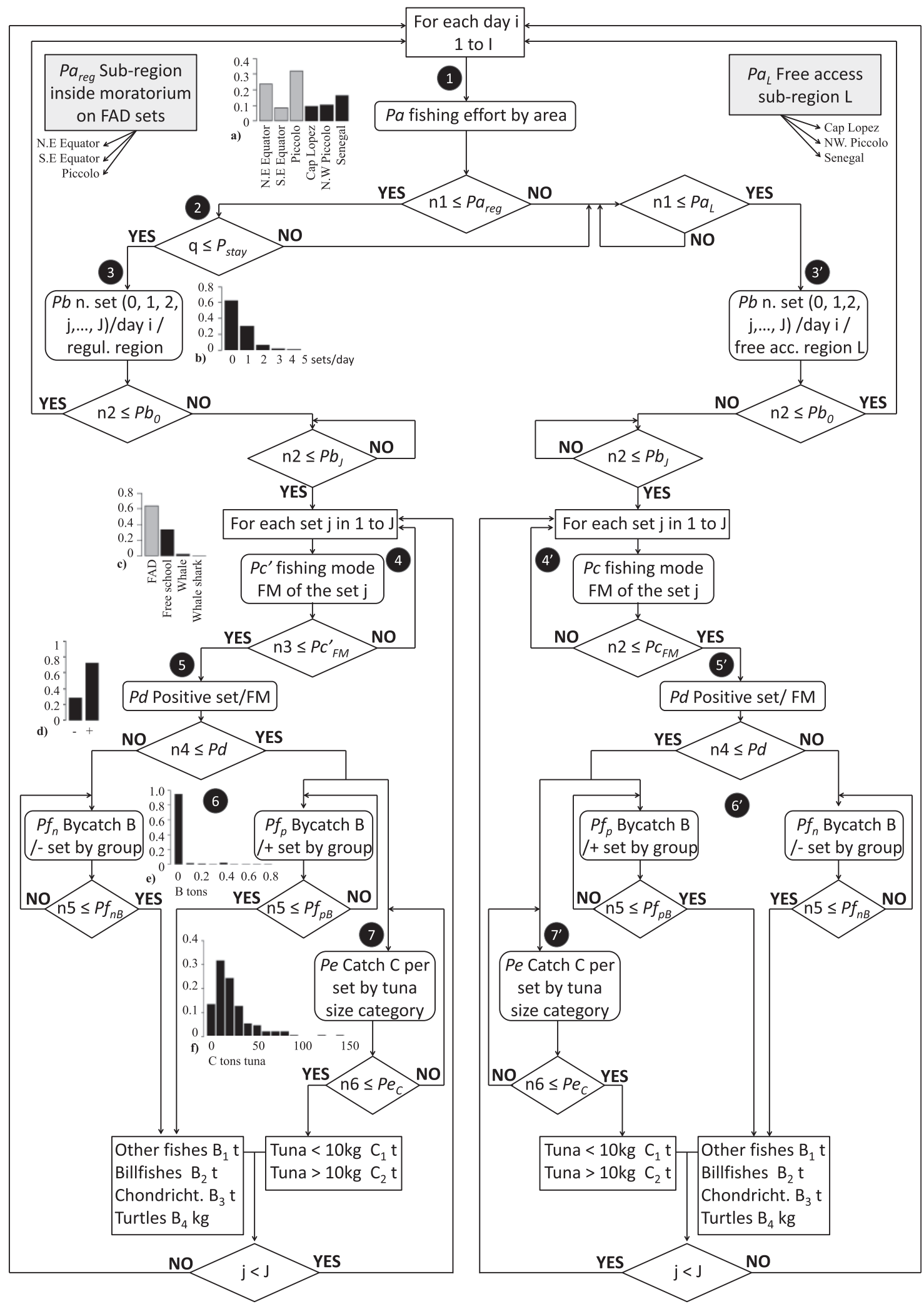

Figure 2. Representation of the decision process used for the Monte Carlo simulation. Histograms (illustrative only, as for the simulation cumulative histograms have been used) given as examples, are probabilities of (a) fishing in each sub-region during season 4 in the Atlantic Ocean $(\mathrm{Pa})$, (b) number of fishing set per day in N.E Equator ( $P b$ N.E Equator), (c) fishing mode when there is no Moratorium on FAD (Pc), (d) free school set successful or not ( $P d$ free school set), (e) bycatch of other bony fishes in a free school set ( $P f$ other bony fishes/free school set), ( $f$ ) catch of tuna $\geq 10 \mathrm{~kg}$ in a free school set (Pe tuna $\geq 10 \mathrm{~kg} /$ free school set). $n(n 1, n 2 \ldots)$ and $q$ are the random numbers drawn and compared to each probability. Rounded rectangles were used for probabilities description. Diamonds boxes represent the comparison between random numbers and probabilities. Rectangles were used for information, number of days or sets increments and model outputs. 
$65.0 \pm 15.8 \%$ for the Spanish fleet (average of 11 French and 31 Spanish operating purse seiners per year in the Atlantic Ocean; and 17 and 25 in the Indian Ocean). In the Indian Ocean, it covered the N Somalia and S Somalia subregions during the SW and INE monsoon periods (i.e. June to November; Figures 1, 3 and 4 ), for which FAD sets accounted for $86.7 \pm 17.7 \%$ of the sets for the French fleet and $90.9 \pm 7.0 \%$ for the Spanish fleet. In order to model a purse-seiner's behavior, during the moratoria period, the fishing effort could be reallocated to areas where any fishing mode was allowed. This meant that if a purse-seiner would normally fish in a sub-region subject to restrictions it could move to another sub-region. Given the proportion of FAD sets mentioned above, it was taken that this would occur in $0.18-0.79 \%$ and $0.81-0.97 \%$ of the cases in the Atlantic and Indian Oceans, respectively, depending on the fleet, sub-region and season considered $\left(P_{\text {stay }}\right.$, Table 1). Two scenarios were tested for each ocean and fleet. In scenario 1 each purse-seiner may reallocate its fishing effort to any of the unrestricted sub-regions depending on its probability of being present in the sub-region considered $(\mathrm{Pa})$. In scenario 2 (the "fishing the line" scenario; Kellner et al., 2007), the purse-seiner reallocated its fishing effort only to adjacent subregions, depending on the probability of being present. In such scenario, in the case of the Atlantic Ocean the simulated vessel may only transfer its fishing effort to N.W Piccolo and Cap Lopez. In the Indian Ocean the fishing effort may only be transferred to NW Seychelles and SE Seychelles (Figure 1). The adjacent Maldives-Chagos sub-region was not included, considering the low fishing effort observed in the fishery data $(<0.5 \%$ of the fishing days).

\section{Simulating 6-month moratoria on FAD activities}

As this study set out to detect the effects of potential six-month FAD moratoria, a simulation, based on the real fishery data, without any ban was tested to provide a baseline. This first simulation would reflect the global current situation of the fishery over the 2005-2014 period (i.e. including the fishing effort restrictions already established by tRFMOs). The two scenarios previously mentioned were then separately simulated for the FAD moratorium defined for each ocean. The major difference from the baseline scenario was that, when a moratorium was simulated, the probability of the occurrence of a FAD set inside the restricted area was redistributed among the remaining fishing modes in proportion to their respective probabilities (the probability $P c$ of setting on a specific fishing mode in the restricted sub-region becoming $P c^{\prime}$, see Table 1).

Each Monte Carlo simulation (i.e. the baseline and the two scenarios) was carried out 1000 times for one fishing year (i.e. average number of fishing days per vessel for each fleet and ocean in the fishery data) of one vessel from a designated European fleet. Each day $i$ of the year, the vessel may fish in any of the subregion with each probability varying depending on the season. For each day i, a random number (n1) was drawn and compared to the probability $\mathrm{Pa}$ ( 1 in Figure 2). The vessel was then assumed to spend the day in one of the restricted sub-regions or in one of the free-access sub-regions (left and right section, respectively in Figure 2). If the vessel was assumed to spend the day $i$ in a restricted sub-region, a random number $\mathrm{q}$ was drawn and compared to the probability of staying in this sub-region $P_{\text {stay }}$ (see Table 1 for details; 2 in Figure 2 ). If $\mathrm{q} \leq P_{\text {stay }}$ the vessel would stay in the sub-region and the process would go to step 3 , otherwise another number $\mathrm{n} 1$ was drawn and compared to the probability $P a_{L}$ with only the unrestricted sub-regions to determine where the fishing effort is reallocated. Then a number $\mathrm{n} 2$ was drawn and compared to the probability $\mathrm{Pb}$ of having $\mathrm{j}$ fishing set $(0$ to 5 in the Atlantic Ocean and 0 to 6 in the Indian Ocean) during day $\mathrm{i}$ ( 3 or 3 ' in Figure 2). If 0 fishing set was drawn, then the simulation continued directly to the following day $(i+1$; back to step 1 in Figure 2), otherwise $j$ fishing sets were simulated successively. The same process was repeated to determine the fishing mode associated with each set $\mathrm{j}$ (n3 vs $P c$; see 4 or 4 ' in Figure 2) and whether the set for this fishing mode was successful or not (n4 vs. $P d$, see 5 or $5^{\prime}$ in Figure 2). To characterize the uncertainty in the catch of tuna, as well as in the bycatch, 4 random numbers n5 were generated for all cases (fishing set successful or not, as it was assumed that an unsuccessful set may have a bycatch, see 6 or 6 ' in Figure 2) and compared to the probabilities $P f n$ or $P f p$ of having $\mathrm{B} t$ of bycatch per species group. If the set was successful, 2 new random numbers were generated and compared to the probabilities $P e$ of having $\mathrm{C} t$ of tuna caught per size category (7 or 7' in Figure 2).

In order to facilitate the comparison between oceans and fleets, the results in terms of (i) number of sets per fishing mode, (ii) tuna catch for each size category, and (iii) bycatch per species group, were calculated on a vessel basis and by year for all subregions taken together. The statistical difference between the two simulated Monte Carlo distributions was then tested using a Kolmogorov-Smirnov test. All the analyses were conducted using R software v.3.0.2 (R Development Core Team 2014).

\section{Results}

The simulation of 6-month moratoria in the eastern Atlantic and western Indian Oceans gave different results depending on the parameter considered (i.e. number of sets, catch, bycatch), as well as on the ocean and the fleet (Table 2). Overall, the results showed a decrease in FAD sets and an increase in free school sets in both oceans. The resulting total tuna catch decreased in the Indian Ocean, but increased in the Atlantic Ocean. In the Indian Ocean only, there was also an increase in some megafauna associated sets. There were contrasted results for the bycatch depending on the species group, the ocean and the fleet.

Firstly, for the two main fishing modes, FAD and free school sets, the simulation of a six-month FAD moratorium gave similar predictions for all combinations of scenario, ocean and fleet. The highest decrease in FAD sets would be in the Indian Ocean for the Spanish fleet, from an average of 155.8 FAD sets/year/vessel to 134.2 sets/year/vessel. The highest increase in number of free school sets would be in the Atlantic Ocean for the French fleet, from an average of 131.8 sets/year/vessel to 153.5 sets/yr/vessel (Table 2 and Figures 5 and 6). The numbers of whale and whale shark associated sets would not change in the Atlantic Ocean (Table 2 and Figure 5). In the Indian Ocean, the number of whale associated sets would increase by $\sim 0.6-0.8 \mathrm{set} / \mathrm{yr} / \mathrm{vessel}$ for the French fleet and the number of whale shark associated sets would increase by $0.1-0.2 \mathrm{set} / \mathrm{year} / \mathrm{vessel}$ for both fleets (Table 2 and Figure 6).

Secondly, for the tuna catch, the predictions were similar between fleets but differed between oceans (Table 2 and Figures 5 and 6). In the Atlantic Ocean, small tuna catch $(<10 \mathrm{~kg})$ would decrease by $14-57$ tons $(\mathrm{t}) /$ year/vessel for the French fleet and by 67-317 t/year/vessel for the Spanish fleet. On the contrary, large tuna catch $(\geq 10 \mathrm{~kg})$ would increase by $161-228 \mathrm{t} /$ year/vessel for 

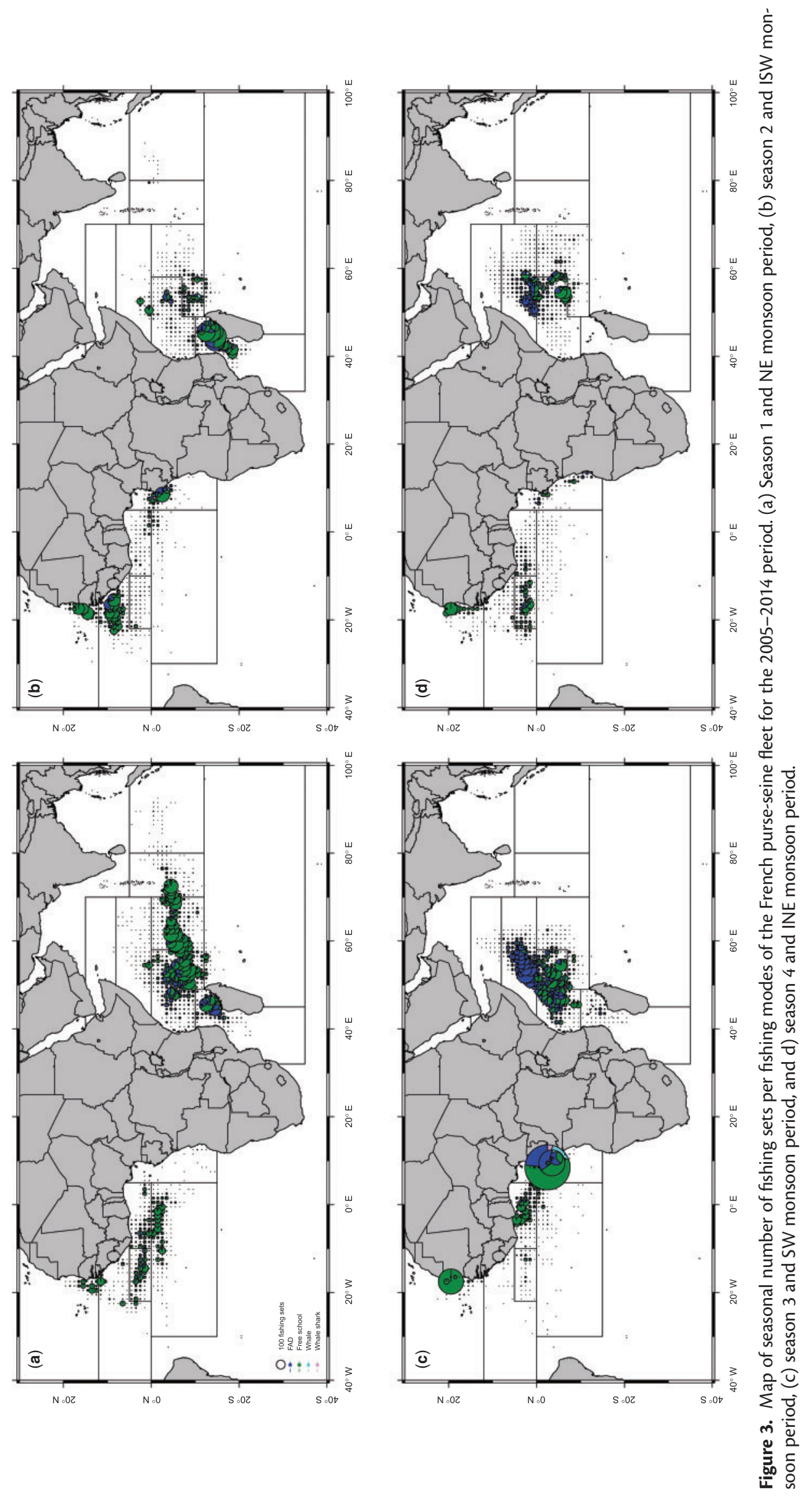


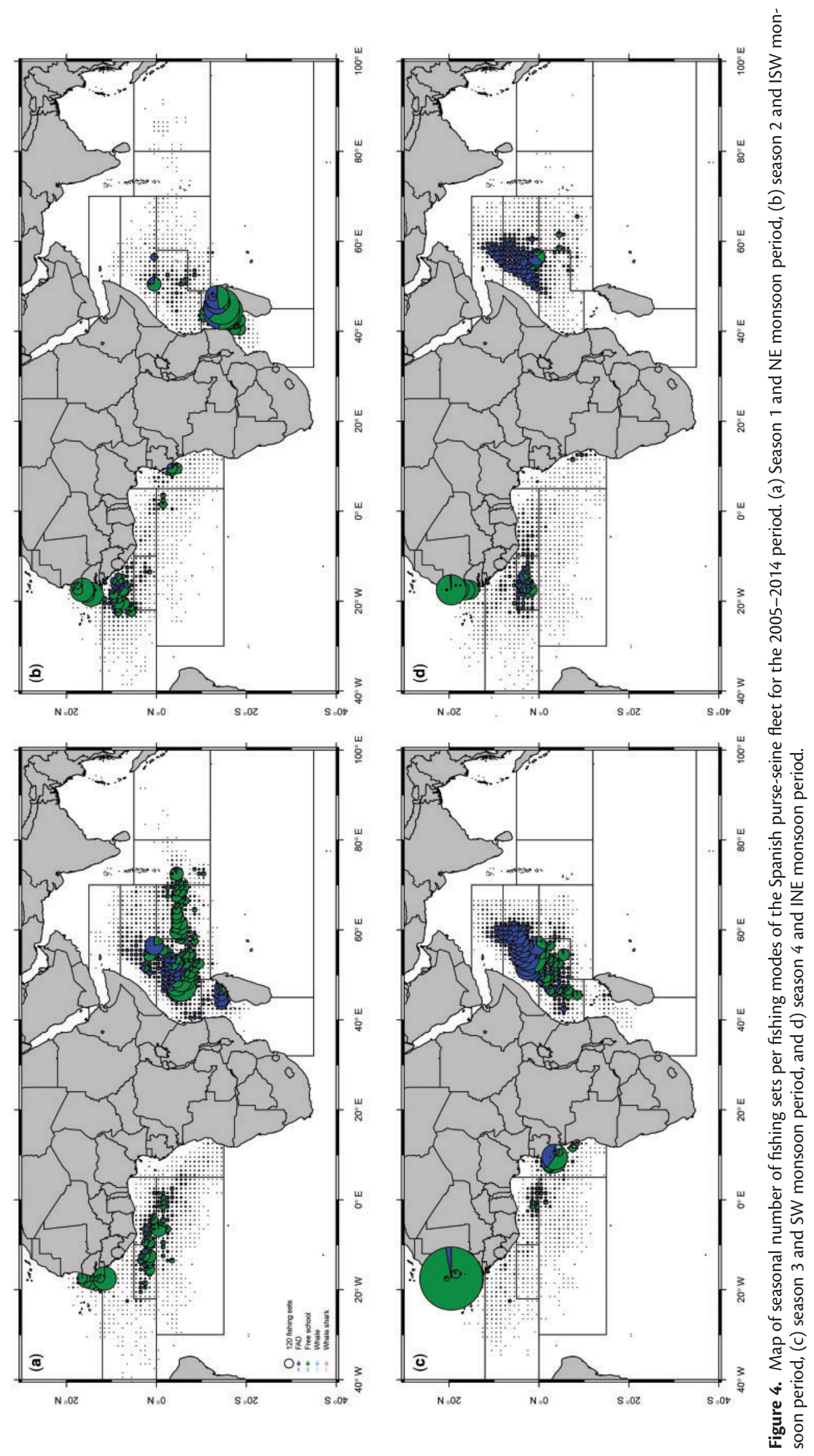


Table 2. Results of Monte Carlo simulations of 6-month moratoria on FAD activities in specific area and period of the eastern Atlantic (AO) and western Indian Oceans (IO) and per fleet (French FR and Spanish SP).

\begin{tabular}{|c|c|c|c|c|c|c|c|c|c|c|c|c|c|}
\hline Ocean & Fleet & Sc. & FAD & FrSc & WHA & WHS & $\begin{array}{l}\text { Tuna } \\
<10 \mathrm{~kg}(\mathrm{t})\end{array}$ & $\begin{array}{l}\text { Tuna } \geq \\
\text { 10kg }(t)\end{array}$ & $\begin{array}{l}\text { Total tuna } \\
\text { catch }(t)\end{array}$ & $\begin{array}{l}\text { Fishes } \\
(t)\end{array}$ & $\begin{array}{l}\text { Billfishes } \\
(t)\end{array}$ & $\begin{array}{l}\text { Sharks } \\
(t)\end{array}$ & $\begin{array}{l}\text { Turtles } \\
\text { (kg) }\end{array}$ \\
\hline \multirow[t]{6}{*}{$\overline{\mathrm{AO}}$} & FR & $\mathrm{BL}$ & 54.1 & 131.8 & 4.6 & 1.7 & 1922.3 & 2417.6 & 4339.9 & 17.1 & 8.9 & 6.5 & 395.8 \\
\hline & & 1 & -13.8 & +21.7 & +0.1 & +0.0 & -56.8 & +160.9 & +104.1 & -4.3 & +0.1 & +1.1 & +47.7 \\
\hline & & 2 & -8.1 & +15.6 & +0.2 & +0.1 & -14.3 & +228.3 & +214.0 & -2.0 & +0.4 & +1.5 & +110.2 \\
\hline & SP & $\mathrm{BL}$ & 84.1 & 94.2 & 1.3 & 1.3 & 3196.3 & 2828.0 & 6024.3 & 24.2 & 4.6 & 5.0 & 239.1 \\
\hline & & 1 & -12.9 & +20.2 & +0.1 & 0.0 & -316.8 & +479.2 & +162.4 & -3.5 & 0.0 & +1.0 & +59.6 \\
\hline & & 2 & -4.5 & +12.8 & +0.1 & 0.0 & -67.0 & +284.1 & +217.1 & +0.2 & +0.3 & +1.5 & +99.1 \\
\hline \multirow[t]{6}{*}{10} & FR & $\mathrm{BL}$ & 118.2 & 98.3 & 6.0 & 1.0 & 3308.4 & 2575.7 & 5884.1 & 100.8 & 9.1 & 18.0 & 104.8 \\
\hline & & 1 & -21.4 & +13.1 & +0.6 & +0.1 & -641.6 & +253.5 & -388.1 & -11.7 & -0.7 & -3.1 & -21.3 \\
\hline & & 2 & -21.2 & +12.5 & +0.8 & +0.1 & -628.5 & +259.9 & -368.6 & -13.1 & -0.3 & -3.1 & -21.8 \\
\hline & SP & $\mathrm{BL}$ & 155.8 & 91.8 & 0.7 & 0.9 & 6509.9 & 2799.9 & 9309.8 & 135.8 & 9.7 & 25.2 & 110.4 \\
\hline & & 1 & -26.6 & +13.2 & 0.0 & +0.1 & - 1707.4 & +151.9 & -1555.5 & -16.8 & -0.1 & -6.3 & -18.8 \\
\hline & & 2 & -25.8 & +12.3 & +0.1 & +0.2 & -1686.8 & +176.7 & -1510.1 & -15.4 & -0.6 & -6.3 & -14.3 \\
\hline
\end{tabular}

For each simulation, the fishery indices are given as an average per year and vessel for the baseline simulation (BL, i.e. current situation without the simulated moratorium), then as the difference between this value and the average of the parameter for each scenario of a simulated FAD moratorium. Bold font represents significant increase or decrease and italic no significant difference of the fishery index from the baseline (based on Kolmogorov-Smirnov tests). FAD, fish aggregation device set; FrSc, free school set; Sc., scenario; WHA, Whale associated set; WHS, whale shark associated set.

the French fleet and by 284-479 t/year/vessel for the Spanish fleet. Therefore, the total tuna catch would increase for both fleets by 104-217 t/year/vessel. In the Indian Ocean, similar predictions were found for the tuna catch by category: small tuna catch would decrease (629-642 and 1687-1707 t/year/vessel for the French and Spanish fleets, respectively), and large tuna catch would increase (254-260 and 152-177 t/year/vessel for the French and Spanish fleets, respectively). However, here the total tuna catch would decrease by 369-388 t/year/vessel for the French fleet and by $1510-1555 \mathrm{t} /$ year/vessel for the Spanish fleet.

Finally, results were variable for the different bycatch groups. The bycatch of other bony fishes and billfishes would mainly decrease in both oceans, as would the bycatch of chondrichthyans and turtles in the Indian Ocean while increasing in the Atlantic Ocean. Looking in further details for each group, the bycatch of other bony fishes would decrease, for all cases, by 0-16.8 t/year/ vessel (Table 2; Figures 5 and 6). Billfishes bycatch would also decrease in the Indian Ocean (by 0.1-0.7 t/year/vessel) but would be stable or increase slightly in the Atlantic Ocean $(+0.3-0.4$ t/year/ vessel). Chondrichthyans bycatch would increase in the Atlantic Ocean (by 1.0-1.5 t/year/vessel) but would decrease in the Indian Ocean (by 3.1 and 6.3 t/year/vessel for the French and Spanish fleets, respectively). Similarly, turtles bycatch would increase in the Atlantic Ocean (by 47.7-110.2 kg/year/vessel) and decrease in the Indian Ocean (by 21.3-21.8 and 14.3-18.8 kg/year/vessel for the French and Spanish fleets, respectively).

\section{Discussion}

It is commonly accepted that fisheries have a direct impact on the whole marine ecosystem and for this reason the EAF is being promoted as a framework for sustainable development, recognizing the interdependence between human well-being and ecosystem health (Garcia et al., 2003). However, although this principle is generally accepted and some initiatives are under considerations (Juan-Jordá et al., 2015), the types of action needed to set up EAF management plans are still not set up by tRFMOs. For various reasons (lack of time, lack of data for non-targeted species), the multi-annual management plans adopted by tRFMOs, even with the recent application of the management strategy evaluation
(MSE), have had a very limited scope. For instance, the focus has been on the risk of the spawning-stock biomass (SSB) of the targeted tuna species falling below the level at which recruitment is likely to be impaired. Several time-areas fishing effort regulation measures have thus been implemented. However, there has been little, if any, consideration of the ecological impact of these fishing restrictions, specifically for non-target species.

Monte Carlo simulations were used in this study to evaluate the consequences of wide-area FAD moratoria on tuna resources, as well as on the main groups of bycatch species and megafauna associated with the purse-seine fishery. This approach was used as the multiple uncertainties can propagate through the searching and fishing processes characteristic of a fishing trip by a purseseiner. However, some limitations were not accounted for in the simulation process, for instance (i) the annual variability of the data could not be easily included in the models, (ii) the catch of all tuna species were grouped into the same size categories because of the type of data used (i.e. non-corrected logbooks, see Materials and Methods for details), (iii) while some bycatch species have different biology and ecology (e.g. marlins and sailfishes, sharks and rays) and some vulnerable species may benefit having a special focus (e.g. silky sharks, manta rays), bycatch species were grouped into four categories in order to give a general picture of the whole epipelagic ecosystem, and (iv) each purse-seiner could operate in only one sub-region in a given day. Some fishery factors could also not be accounted for in the simulations (e.g. use of supply vessels, limitation in the number of FADs, intervessel communication [see European Research Project Catch, Effort, and eCOsystem impacts of FAD-fishing (CECOFAD) for details]), as well as future fisher's behavior-at-sea in response of extended time-area moratoria. It addition, it would have been useful to validate the model, for example using historical data. However, as fishing strategies and spatial distribution in fishing effort have changed over time, particularly between the periods 1980-2004 and 2005-2014, the use of data covering a period before 2005 to validate the model would not have been appropriate. Ultimately we considered that the increase in fishing effort in some sub-regions following purse-seiners reallocation (e.g. average of $15.9 \pm 17.7$ increase in the number of fishing sets 

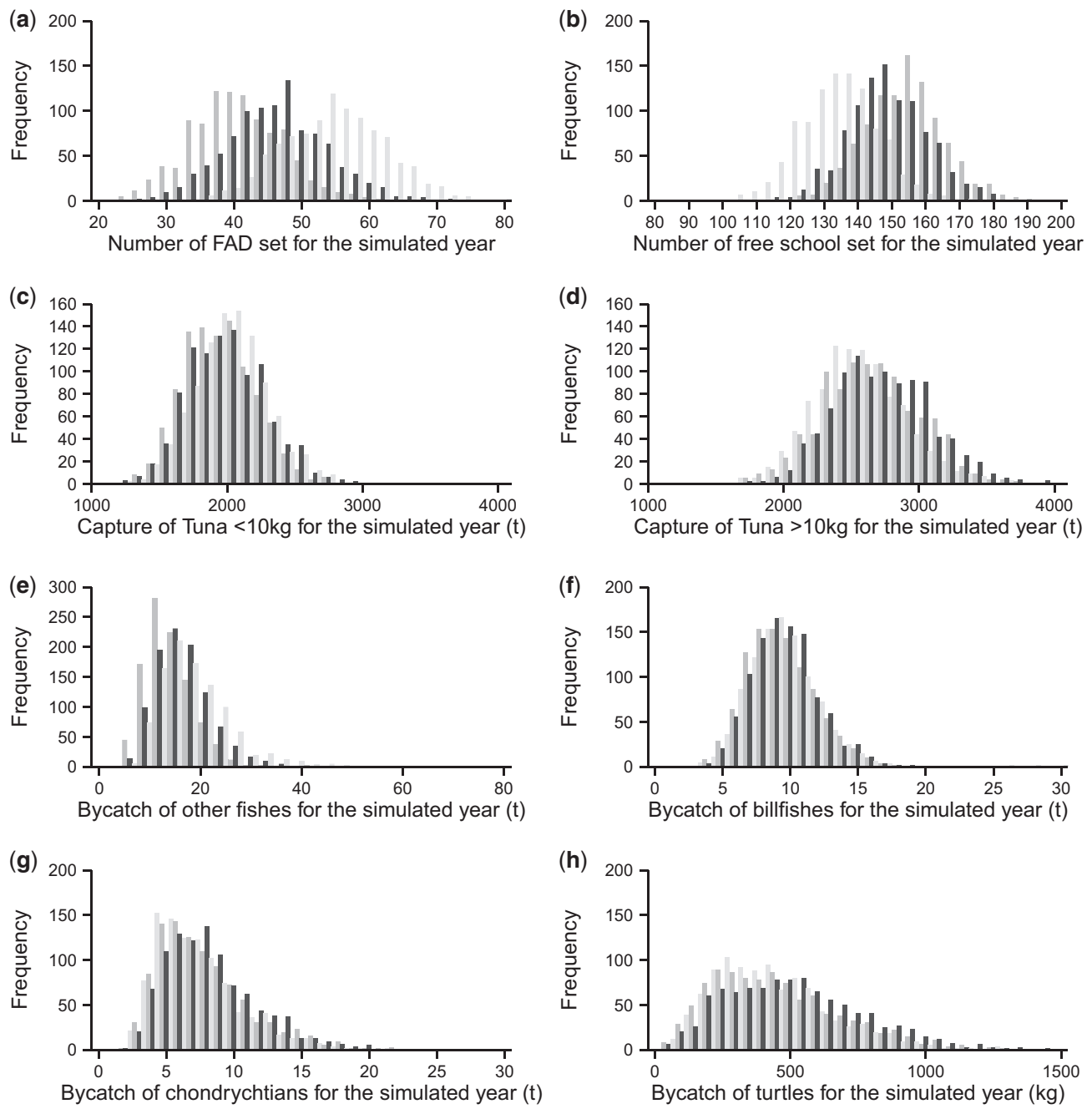

Figure 5. Simulated fishery indices: (a) FAD set, (b) free school set, (c) catch of tuna $<10 \mathrm{~kg}$, (d) catch of tuna $\geq 10 \mathrm{~kg}$, (e) bycatch of other bony fishes, ( $f$ ) bycatch of billfishes, ( $g$ ) bycatch of chondrichthyans and $(h)$ bycatch of turtles, for one French purse-seiner over one fishing year with a moratorium on FAD during season 1 and 4 (dark grey $=$ scenario 1 ; black $=$ scenario 2 ) in the Atlantic Ocean, compared to the baseline (light grey).

performed per vessel and sub-region per year) would not lead to tuna depletion, at least at the large scale considered. While local depletion has been described in demersal fisheries (Pastoors et al., 2000), and may sometimes occur in case of hyper-concentration of tunas at smaller spatio-temporal levels (Fonteneau et al., 2008), there are no evidences that it would occur for highly migratory tuna species at larger scales in our simulations considering constant fishing effort in the whole studied area. In the eastern Atlantic and western Indian Oceans, FAD sets generally capture more tuna $<10 \mathrm{~kg}$, mainly adult skipjack with juvenile yellowfin and bigeye tunas, as well as a greater bycatch, than free school sets. Wide area FAD moratoria could, therefore, be introduced in the future in order to protect juveniles of tropical tunas, but also limit the impact of purse-seine fishery by reducing the bycatch of endangered species. As expected, owing to the characteristics of the time-area strata selected for the FAD moratoria, the results of the iterative "fishing-day" model showed a decrease in the number of FAD sets. This was partially or totally balanced, depending on the ocean, by an increase in the number of free school sets. Indeed the overall number of sets increased in the
Atlantic Ocean but decreased in the Indian Ocean. Consequently the catch of tuna $<10 \mathrm{~kg}$ generally decreased while the catch of tuna $\geq 10 \mathrm{~kg}$ increased. In the Indian Ocean, both scenarios were equivalent, with the fishing effort mainly reallocated to areas adjacent to the moratorium (see Figure A.3-A.4 as supplementary material). This is a well known effect for marine protected areas (Kellner et al., 2007; Torres-Irineo et al., 2011). It was however not the case in the Atlantic Ocean, where the number of free school sets highly increased $(+13$ sets for each fleet) in the Senegal subregion (Figure A.6). This sub-region was historically known for fishing on free school of skipjack tuna (Fonteneau 2009). This may thus explain the high difference in the capture of tuna catch per category between oceans.

While the trend of tuna catch per commercial category was the same, the consequences of the simulated moratoria on the overall tuna catch varied between oceans. At the scale of the fishery, catch could increase up to 2500 and 8000 t/year in the Atlantic Ocean and decrease up to 6500 and 39000 t/year in the Indian Ocean, for the French and Spanish fleets, respectively. Therefore, the net loss in tuna catch could be particularly serious for the Spanish 

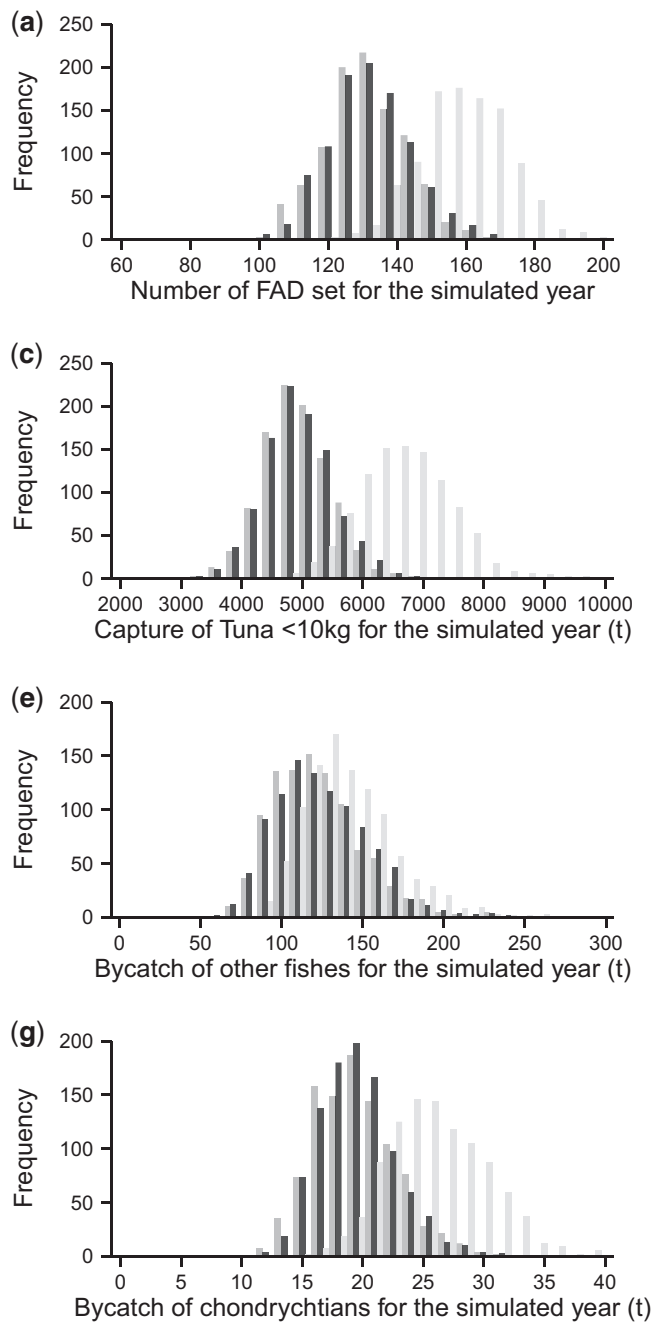
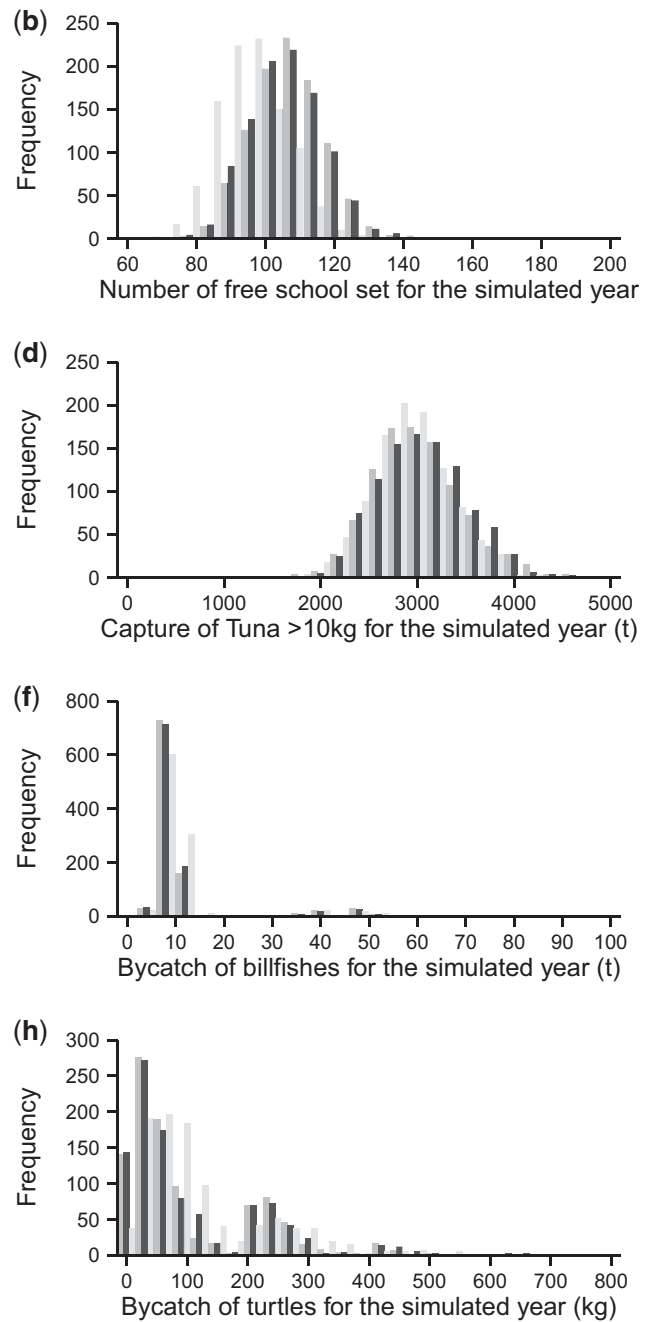

Figure 6. Simulated fishery indices: a) FAD set, (b) free school set, (c) catch of tuna $<10 \mathrm{~kg}$, (d) catch of tuna $\geq 10 \mathrm{~kg}$, (e) bycatch of other bony fishes, ( $\mathrm{f}$ ) bycatch of billfishes, ( $\mathrm{g}$ ) bycatch of chondrichthyans and $(\mathrm{h}$ ) bycatch of turtles, for one Spanish purse-seiner over one fishing year with a moratorium on FAD during SW and INE monsoon periods (dark grey = scenario 1; black = scenario 2 ) in the Indian Ocean, compared to the baseline (light grey).

fleet, where FAD sets, during the period of the simulated moratorium, accounted for $36 \%$ of their total yearly catch. It should be mentioned that the price of the species and size categories of tuna should be kept in mind. Large tunas have higher commercial values than smaller ones, even if high fluctuations have occurred and the price differential between small and large tunas may affect the choice of future fishing strategies (free schools vs. FADs).

The main reason for the implementation of more extensive time-area restrictions on FAD sets is to limit the capture of juvenile tunas but the reduction of bycatch appears as a reasonable secondary objective. This second objective would be fully achieved in the Indian Ocean, where the bycatch of all groups would decrease. In the Atlantic Ocean the bycatch of other bony fishes, which represent a large proportion of the bycatch on FAD sets would also decrease (Table 2, Figures 5 and 6). The bycatch of billfishes would however remain relatively stable in this Ocean (or slightly increase). A previous study using French and Spanish observer data found that the introduction of a FAD moratorium led to a significant decrease in the catch of marlins, which are mainly captured on FAD sets. At the same time it also led to a significant increase in the catch of sailfishes, mainly captured in free school sets (Gaertner et al., 2002). Therefore the pattern observed in the bycatch of billfishes in the Atlantic Ocean, may be explained by the same phenomenon. Further details in the species captured would allow a more comprehensive vision of the pattern of billfishes bycatch during the simulated moratorium. The capture of chondrichthyans and turtles increased in the Atlantic Ocean. Turtle bycatch is more widespread in both free school and FAD sets in the Atlantic Ocean than in the Indian Ocean, where it is concentrated in the area covered by the simulated moratorium (Amandè et al., 2010, 2012; Bourjea et al., 2014). The chondrichthyans bycatch, mainly constituted by silky sharks, is higher in both oceans in FAD sets than in free school sets. The main area for silky shark bycatch in the Indian Ocean is within the area covered by the simulated moratorium ( $\mathrm{N}$ and $\mathrm{S}$ Somalia). However in the Atlantic Ocean areas of chondrichthyans bycatch are mainly off Mauritania and Cape Lopez, which are not part of the moratorium area (Torres-Irineo et al., 2014). Therefore, the 
reallocation of the fishing effort to unrestricted areas, with higher chondrichthyans bycatch in both free school and FAD sets might explain the increase predicted in the Atlantic Ocean. Conversely, fishing effort reallocation away from areas with high chondrichthyans bycatch might explain the decrease predicted in the Indian Ocean. In addition, it must be stressed that manta rays are sometimes caught in free school sets and mostly in Cape Lopez and Piccolo NW sub-regions, but this is rare compared to the capture of silky sharks.

This study assessed the effects of time-area closures for FAD activities. However, more than one restriction may be in force at any one time. In the Indian Ocean, the IOTC has banned intentional sets on whales and whale sharks since 2013 (IOTC, 2013). This does not appear in our data as the whole 2005-2014 period was considered. However, the study predicted that a six-month FAD moratorium in the Indian Ocean would lead to a slight increase in whale and whale shark associated sets. At fishery scale, this would represent 116 whale associated sets per year (100 sets without the moratorium for the French fleet only) and 92 whale shark associated sets ( 80 sets without the moratorium for the French and Spanish fleets). Full observer coverage has not yet being achieved in the Indian Ocean owing to the lack of space onboard the purse-seiners (armed guards onboard to prevent piracy). While electronic observers (onboard video camera) are currently tested, the lack of full observer coverage may lead to under report or fail to report megafauna associated sets by skippers, which could, as simulated, reallocate fishing effort toward these fishing modes.

The current time-area closure in the Indian Ocean (IOTC, 2012), has already proved to be too small (in space and time) to be effective in protecting tuna stocks (Kaplan et al., 2014). Our study showed that a more extensive six-month restriction on FAD activities would limit the catch of small tuna (skipjack and juveniles) and reduce the bycatch of all groups of species, including endangered species such as sharks and turtles. In the Atlantic Ocean, the moratorium tested, like previous ones, would not completely fulfill its objectives. While the number of FAD sets is lower in the Atlantic Ocean, it is more widespread in space compared to the Indian Ocean. Therefore, more flexible restrictions could be considered in the Atlantic Ocean. For instance, spatiotemporal bans taking into account FAD fishing, as well as sharks and turtles bycatch hotspots could be investigated. A dynamic management measure based on the main FAD fishing areas each year could also be considered. This would however be very difficult to implement in this ocean wide and international fishery. A more restrictive FAD limitation per purse-seiner in the whole Atlantic Ocean could also be considered. Recently, ICCAT and IOTC have adopted the limitation of 500 and 425 active FAD buoys, respectively, per purse-seiner at any time.

\section{Conclusion}

Monte Carlo simulations were carried out to examine various scenarios for spatially reallocating the fishing effort or changing fishing practices (i.e. fishing mode) following the introduction of a six-month FAD moratorium. The simple iterative "fishing-day" model accounted for the probability of the occurrence of several different fishing events and skippers' on-the-spot decisions based on European purse-seine fishery data from the 2005-2014 period. However, this approach is by definition unable to take account of the uncertainty associated with the skippers' behavior-at-sea in the future. While allowing for this limitation, this study gave an insight into the trade-off between the advantages and disadvantages of extensive time-area closures in the eastern Atlantic and western Indian Oceans in an EAF framework. The results showed that the objectives of such measures would be achieved in the Indian Ocean, with a significant reduction in the capture of small tuna (the actual reduction in the juvenile tuna catch needs to be evaluated), as well as a decrease in all bycatch groups. In the Atlantic Ocean, while the catch of small tuna decreases, results were contrasted for bycatch indicating that different type of complementary measures should be investigated. By assessing the effect of restrictions on both the target and bycatch species, and, therefore, the whole community that might be affected by the purse-seine fishery, this study argues in favor of adopting an ecosystem approach to fisheries.

\section{Supplementary data}

Supplementary material is available at the ICESJMS online version of the manuscript.

\section{Acknowledgments}

We thank two anonymous Reviewers and the Editor Jan Jaap Poos for their constructive comments on an earlier version of the manuscript. The authors are grateful to the skippers, fishing companies and observers onboard involved in the logbook data collection and observer programs, which are supported by the French and Spanish National Fisheries Administrations and research institutes (IRD/IEO) within the framework of the EU DCF. L. Escalle is funded by a PhD grant from the University of Montpellier. We would also like to thank the teams of the "Observatoire Thonier" (IRD) and the "Centro Costero de Canarias" (IEO) for providing logbook and observer data.

\section{References}

Amandè, M. J., Ariz, J., Chassot, E., Delgado de Molina, A., Gaertner, D., Murua, H., Pianet, R., et al. 2010. Bycatch of the European purse seine tuna fishery in the Atlantic Ocean for the 2003-2007 period. Aquatic Living Resources, 23: 353-362.

Amandè, M. J., Chassot, E., Chavance, P., Murua, H., de Molina, A. D., and Bez, N. 2012. Precision in bycatch estimates: the case of tuna purse-seine fisheries in the Indian Ocean. ICES Journal of Marine Science, 69: 1501-1510.

Ariz, J., Delgado, A., Fonteneau, A., Gonzales Costas, F., and Pallares, P. 1999. Logs and tunas in the Eastern Tropical Atlantic. A review of present knowledge and uncertainties. Proceedings of the International Workshop on Fishing For Tunas Associated with Floating Objects. IATTC Special Report, 11: 21-65.

Bourjea, J., Clermont, S., Delgado, A., Murua, H., Ruiz, J., Ciccione, S., and Chavance, P. 2014. Marine turtle interaction with purseseine fishery in the Atlantic and Indian oceans: lessons for management. Biological Conservation, 178: 74-87.

Bromhead, D., Foster, J., Attard, R., Findlay, J., and Kalish, J. 2003 A review of the impact of fish aggregating devices (FADs) on tuna fisheries. Final Report to the Fisheries Resources Research Fund. Bureau of Rural Sciences, Canberra, Australia. 122pp.

Capietto, A., Escalle, L., Chavance, P., Dubroca, L., Delgado de Molina, A., Murua, H., Floch, L., et al. 2014. Mortality of marine megafauna induced by fisheries: Insights from the whale shark, the world's largest fish. Biological Conservation, 174: 147-151.

Escalle, L., Capietto, A., Chavance, P., Dubroca, L., Delgado De Molina, A., Murua, H., Gaertner, D., et al. 2015. Cetaceans and tuna purse seine fisheries in the Atlantic and Indian Oceans: Interactions but few mortalities. Marine Ecology Progress Series, 522: 255-268. 
Fonteneau, A. 2009. Atlas of Atlantic Ocean Tuna Fisheries. IRD, Marseille. 190 pp.

Fonteneau, A. 2010. Atlas of Indian Ocean Tuna Fisheries. IRD, Marseille. 70pp.

Fonteneau, A., Lucas, V., Tewkai, E., Delgado, A., and Demarcq, H. 2008. Mesoscale exploitation of a major tuna concentration in the Indian Ocean. Aquatic Living Resources, 21: 109-121.

Gaertner, D., Menard, F., Develter, C., and Ariz, J. 2002. Bycatch of billfishes by the European tuna purse-seine fishery in the Atlantic Ocean. Fishery Bulletin, 100: 683-689.

Garcia, S. M., Zerbi, A., Aliaume, C., Do Chi, T., and Lasserre, G. 2003. The ecosystem approach to fisheries. Issues, terminology, principles, institutional foundations, implementation and outlook. FAO Fisheries Technical Paper, 443:71. pp.

Hallier, J. P., and Parajua, J. I. 1999. Review of tuna fisheries on floating objects in the Indian Ocean. Proceedings of the International Workshop on Fishing For Tunas Associated with Floating Objects. IATTC Special Report, 11: 195-221.

ICCAT 1998. Recommendation [98-01] concerning the establishment of a closed area/season for the use of Fish Aggregation Devices (FADs).

ICCAT 2004. Recommendation [04-01] on a multi-year conservation and management program for bigeye tuna.

ICCAT 2011. Recommendation [11-01] on a multi-annual conservation and management program for bigeye and yellowfin tunas.

IOTC 2012. Resolution 12/13 for the conservation and management of tropical tunas stocks in the IOTC area of competence.

IOTC 2013. Compendium of active conservation and management measures for the Indian Ocean Tuna Commission. Mahé, Seychelles.

Juan-Jordá, M. J., Arrizabalaga, H., Restrepo, V., Dulvy, N. K., Cooper, A. B., and Murua, H. 2015. Preliminary review of ICCAT, WCPFC, IOTC and IATTC progress in applying ecosystem based fisheries management. IOTC Technical Report IOTC-2015-WPEB11-40 70pp.

Juan-Jordá, M. J., Mosqueira, I., Cooper, A. B., Freire, J., and Dulvy, N. K. 2011. Global population trajectories of tunas and their relatives. Proceedings of the National Academy of Sciences of the United States of America, 108: 20650-20655.
Kaplan, D. M., Chassot, E., Amandé, J. M., Dueri, S., Demarcq, H., Dagorn, L., and Fonteneau, A. 2014. Spatial management of Indian Ocean tropical tuna fisheries: potential and perspectives. ICES Journal of Marine Science, 71: 1728-1749.

Kell, L. T. 2011. A standardized way of presenting species group executive sumarises Coll. Vol. Sci. Pap. ICCAT 66: 2213-2218.

Kellner, J. B., Tetreault, I., Gaines, S. D., and Nisbet, R. M. 2007. Fishing the line near marine reserves in single and multispecies fisheries. Ecological Applications, 17: 1039-1054.

Lopez, J., Moreno, G., Sancristobal, I., and Murua, J. 2014. Evolution and current state of the technology of echo-sounder buoys used by Spanish tropical tuna purse seiners in the Atlantic, Indian and Pacific Oceans. Fisheries Research, 155: 127-137.

Marsac, F., Fonteneau, A., and Menard, F. 2000. Pêche thonière et dispositifs de concentration de poissons. Actes De Colloques IFREMER, 28: 15-35.

Pallarés, P., and Petit, C. 1998. Trocical tunas: New sampling and data processing strategy for estimating the composition of catches by species and sizes. Col.Vol.Sci.Pap. ICCAT, 48: 230-246.

Pastoors, M. A., Rijnsdorp, A. D., and Beek, F. A v. 2000. Effects of a partially closed area in the North Sea ('plaice box') on stock development of plaice. ICES Journal of Marine Science, 57: 1014-1022.

R Development Core Team 2014. R: a language and environment for statistical computing. R Foundation for Statistical Computing, Vienna.

Torres-Irineo, E., Amandè, M. J., Gaertner, D., Molina, A. D d., Murua, H., Chavance, P., Ariz, J., et al. 2014. Bycatch species composition over time by tuna purse-seine fishery in the eastern tropical Atlantic Ocean. Biodiversity and Conservation, 23: 1157-1173.

Torres-Irineo, E., Gaertner, D., de Molina, A. D., and Ariz, J. 2011. Effects of time-area closure on tropical tuna purse-seine fleet dynamics through some fishery indicators. Aquatic Living Resources, 24: 337-350.

Vaca-Rodríguez, J. G., and Dreyfus-León, M. J. 2000. Analysis of the fishing strategies of the yellowfin tuna (Thunnus albacares) eastern Pacific fishery based on Monte Carlo simulations of a densitydependent matrix model. Ciencias Marinas, 26: 369-391. 